\title{
Validation of gas phase chemistry in the WRF-Chem model over Europe
}

\author{
Jan Karlický, Peter Huszár, and Tomáš Halenka \\ Department of Atmospheric Physics, Faculty of Mathematics and Physics, Charles University, Prague, \\ V Holešovičkách 2, 18000 Prague 8, Czech Republic \\ Correspondence to: Jan Karlický (jan.karlicky@mff.cuni.cz)
}

Received: 14 January 2017 - Revised: 24 May 2017 - Accepted: 26 May 2017 - Published: 21 June 2017

\begin{abstract}
This work presents the evaluation of the WRF-Chem model applied for a European domain over the year 2008 and employing two different chemical modules. Airbase European station data and E-OBS database are used for validation of the simulated meteorological conditions as well as concentrations of $\mathrm{NO}_{2}, \mathrm{SO}_{2}$ and ozone. In both experiments, underestimation of the amplitude of temperature daily cycle (by about $1{ }^{\circ} \mathrm{C}$ ) and precipitation overestimation (by about $25 \%$ ) were found, with possible impact on chemistry processes due to increased removal via wet deposition. The modelled ozone concentrations match the observations quite well, while the simulated concentrations of other gases show highly negative bias.
\end{abstract}

\section{Introduction}

During the last decades, great progress has been achieved in numerical atmospheric modelling, especially in coupling numerical weather prediction (NWP) models with chemical transport models (CTM). A simple way of coupling NWP models and CTM, the so called off-line approach involving the chemical part of the model driven by an independent NWP model (Grell et al., 2005) has some computational advantages, but neglects the impact of chemistry on meteorological conditions (e.g. via radiation effects). Currently, due to the growth of the available computational capacity, fully on-line approach prevails - see e.g. Grell and Baklanov (2011) for the overview of its advantages. However, even with the fully on-line approach, lots of model inaccuracies still occur in resulting values of gas and aerosol concentrations in validation studies (e.g. Huszar et al., 2012; Tuccella et al., 2012; Huszar et al., 2016). These inaccuracies are caused by simplification used in model design as well as by unreliable model inputs, mainly regarding the emission sources.

The aim of this study is evaluation of the ability of the atmospheric model WRF-Chem to capture the temporal and spatial distribution of short-lived gas concentrations, together with comparison of two chemical modules used within WRFChem. Due to the fact that the emission sources strongly im- pact model results, our analysis can also be taken as partial evaluation of emission sources accuracy.

\section{Experimental setup and data}

For all simulations, Weather Research and Forecasting/Chemistry model (WRF-Chem; Grell et al., 2005), version 3.5.1 is used. WRF-Chem is a mesoscale nonhydrostatic meteorological model with on-line coupled chemistry. In our experiments, a computational domain with $190 \times 206$ grid points $(25 \mathrm{~km}$ horizontal resolution) and 30 vertical levels up to $50 \mathrm{hPa}$ is employed, centered on central Europe (Fig. 1). For long-wave and short-wave radiation transfer, RRTM (Mlawer et al., 1997) and Goddard (Chou and Suarez, 1999) schemes are activated, respectively. Microphysical processes are resolved by the Morrison doublemoment scheme (Morrison et al., 2009). Further, the Noah Land Surface Model (Chen and Dudhia, 2001) for surface layer processes, Yonsei University scheme (YSU PBL; Hong et al., 2006) for planetary boundary layer description and Grell-Freitas (Grell and Freitas, 2014) scheme for convection are used.

As meteorological boundary conditions, the ERA-interim (Dee et al., 2011) dataset is used. For the chemical part, lateral boundary conditions are computed from MOZART-4 re- 


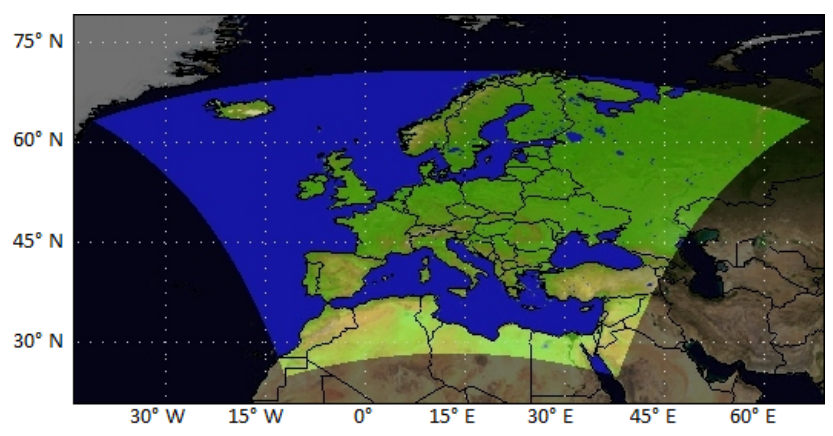

Figure 1. Position of the model domain in regular longitudelatitude grid.

analysis driven fields (Emmons et al., 2010). Finally, upper boundary conditions are determined from climatology.

Anthropogenic emissions are taken from the TNO MACCII database. Biogenic emissions are on-line computed by the MEGAN model (Guenther et al., 2006). Emissions from biomass burning are compiled from the Fire Inventory from NCAR (FINN; Wiedinmyer et al., 2011).

In the presented study, two mechanisms of gas-phase chemistry are used, namely Carbon Bond Mechanism, version Z (CBMZ; Zaveri and Peters, 1999) and Regional Acid Deposition Model, v. 2 (RADM2; Stockwell et al., 1990). Both chemical mechanisms are tested with the above mentioned setup on one-year long simulations with 5-days spinup. The simulations are run freely without any restarts or nudging procedure. The wet scavenging of main water soluble gases is included only in convective updrafts on the sub-grid scale, coupled with a simple sub-grid scheme of the aqueous chemistry. Aerosol chemistry is not included in these simulations.

For validation of the physical part of the WRF-Chem model, the E-OBS (v. 11) dataset (Haylock et al., 2008) is used. E-OBS offers a $0.25^{\circ} \times 0.25^{\circ}$ resolution gridded data of temperature and precipitation fields. Model biases are determined in terms of temperature means, maxima, minima and precipitation sums.

The concentrations of the pollutants of interest, $\mathrm{O}_{3}, \mathrm{NO}_{2}$ and $\mathrm{SO}_{2}$, are evaluated against the Airbase database (v. 7), which includes European station-based concentration measurements. For validation, background stations were taken into account, however, specific types of stations (rural, suburban, urban) are distinguished within the validation to investigate the accuracy of model predictions under different chemical regimes given by the type of the station.

The ability of WRF-Chem atmospheric model to capture the total amount and temporal and spatial distribution of the pollutants is evaluated in terms of the following quantities: bias - averaged model relative deviation from reference data, correlation coefficient - correlation between model and reference time series, slope - regression coefficient of model values on the reference values.

\section{Results}

In terms of domain and seasonal averages, temperature biases are below $1{ }^{\circ} \mathrm{C}$ (Fig. 2). Temperature maxima are shifted to lower values in comparison to temperature mean and minima, which consequently leads to reduced amplitude of the daily cycle. Precipitation is overestimated by the model in all seasons, especially in spring. This wet bias can strongly impact the model chemistry due to overestimated wet scavenging of water-reactive gases during the convective season, when the convective precipitation dominates over the large scale one.

To compare the simulated and station-based pollutant concentrations, statistics introduced in Sect. 2 were also applied to ozone, $\mathrm{NO}_{2}$ and $\mathrm{SO}_{2}$ series, separately for individual station types (Fig. 3). The total amounts of $\mathrm{NO}_{2}$ and $\mathrm{SO}_{2}$ are underestimated for all station types, though more in suburban and urban stations. Conversely, the total ozone amount is overestimated at these stations. The highest values of correlations are achieved for ozone (at all station types). On the other hand, the correlations of the $\mathrm{SO}_{2}$ series are very low. That is also true for the values of slope, with the best match again found for the ozone series. Differences between series obtained by the CBMZ and RADM2 schemes are low for $\mathrm{NO}_{2}$ and $\mathrm{SO}_{2}$. For ozone, CBMZ simulation is less biased with slightly higher correlations and slope.

Figure 4 plots the comparison of the averaged annual cycles for all targeted pollutants and station types. As before, the best agreement was found for ozone, particularly at the rural stations. The variance of the model values is, however, much smaller. For suburban and urban stations, the monthly averaged model values are largely overestimated, especially in the simulation using the RADM2 scheme. For $\mathrm{NO}_{2}$ and $\mathrm{SO}_{2}$, the model values are close to observations only at the rural stations. At the other types of stations, model values are greatly underestimated, which can be seen also in Fig. 3 as negative total biases. In most cases, the variance is distinctly underestimated by the model. Differences between the two model setups are negligible.

In Fig. 5, a comparison of averaged model and observed daily cycles of ozone for winter and summer is seen. In summer, daily maxima are captured accurately. The daily minima during early morning are overestimated, resulting in underestimation of the daily amplitude by the model. In winter season, too, model values have lower daily amplitude. Moreover, the simulation with the RADM2 scheme fails to capture the double maximum in the daily cycle.

\section{Discussion}

Although this study is primarily focused on validation of the chemical part of WRF-Chem, a short comparison of model and E-OBS meteorology is provided, to ensure that the model meteorology is not too departed from observations to have a significant impact to chemistry. Results showed that differ- 

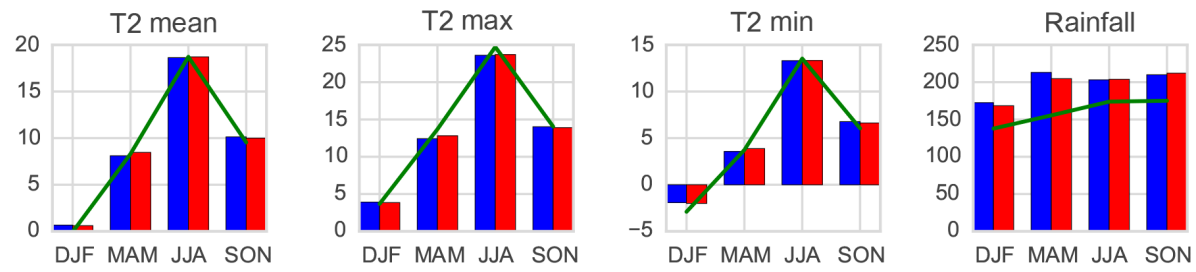

Figure 2. Averaged seasonal modelled temperature $\left({ }^{\circ} \mathrm{C}\right)$ and precipitation (mm; CBMZ - blue, RADM2 - red). Green curve stands for the seasonal values given by E-OBS.
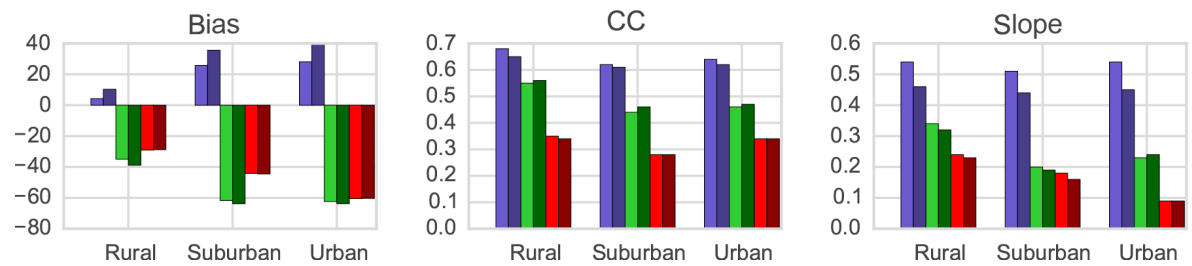

Figure 3. Averaged biases (\%), correlation coefficients (CC) and slopes of model and station daily values for rural, suburban and urban stations. The specific gases are indicated by colors: Ozone - blue, $\mathrm{NO}_{2}$ - green, $\mathrm{SO}_{2}$ - red; lighter colors mean the CBMZ chemical mechanism, darker RADM2.

ences between simulation with CBMZ and RADM2 chemical modules are, in terms of meteorology, negligible, because no impact of gas-phase chemistry on meteorology via radiation is considered. The only source of these differences are the slightly modified geographic static input data. Different versions of standard WRF static input were adopted in simulations, which resulted in slightly modified values of land-use type, fraction of vegetation and other surface parameters in a very few grid-points across the domain. These differences were enhanced during the model integration by the non-linear higher order effects, giving a first guess of the internal model variability. The findings of Mar et al. (2016) were similar - they have shown that the differences between two simulations without aerosol-radiative effects are small, but not zero. The lower daily amplitude of temperature is probably caused by overpredicted cloudiness in the model (also seen in Huszar et al., 2016), which can further cause lower daily amplitude of ozone concentrations. Higher convective precipitation, as was mentioned before, lowers concentration of water-reactive gases due to wet scavenging, so it can be one of the possible reasons for negative biases of $\mathrm{SO}_{2}$, and partly of $\mathrm{NO}_{2}$, in the convective season.

In agreement with the results of Huszar et al. (2012), Tuccella et al. (2012) or Huszar et al. (2016), the correlation values are substantially higher for ozone than for other species (Fig. 3). Values of correlation coefficients, too, are comparable to the mentioned works. A possible reason is that ozone is a secondary pollutant, with spatial distribution less variable near the emission sources than $\mathrm{SO}_{2}$ (or, partly $\mathrm{NO}_{2}$ ), so it could be captured by model with $25 \mathrm{~km}$ resolution much better than primary pollutants. Another reason is that chemical schemes are designed and tuned to achieve correct ozone concentrations, while larger model biases persist for primary pollutants (Kuhn et al., 1998; Huszar et al., 2012). The overall bias of $\mathrm{SO}_{2}$, which is negative for all stations, is not in agreement with the above mentioned studies. However, it can be attributed to the already mentioned overestimation of convective precipitation and to the better vertical distribution of emissions, which is especially important for $\mathrm{SO}_{2}$ that is often emitted from tall stacks (Huszar et al., 2012). Another reason can lie in the used parameterization of planetary boundary layer (YSU PBL; Hong et al., 2006), which was found to over-predict PBL height, resulting in stronger vertical transport (e.g. Misenis and Zhang, 2010 showed that this scheme, in general, poorly represents nocturnal PBL).

Annual cycles (Fig. 4) at rural stations are captured with similar accuracy as in Huszar et al. (2012) or Huszar et al. (2016), with a little improvement for ozone, but with model annual cycle of $\mathrm{SO}_{2}$ shifted to lower values. In general, simulations with either chemical mechanism overestimate ozone, especially for suburban and urban stations and in the nighttime (Fig. 5). This somewhat contrasts with the conclusion by Im et al. (2015), who compared model results against rural background stations and found negative biases in ozone concentrations during daytime. Overestimation of ozone at non-rural stations can be explained by coarse model resolution and the related reduced NO-titration (Im et al., 2015). Faster dilution of $\mathrm{NO}_{x}$ leads to more effective ozone production (Vautard et al., 2007). The lower daily amplitude of summer ozone daily cycle (Fig. 5) is nearly the same as the amplitude described by Huszar et al. (2012) and Huszar et al. (2016), with the missing early-morning decrease, too. In winter, there is a difference between specific chemical mechanisms; simulation with CBMZ scheme produces a double 


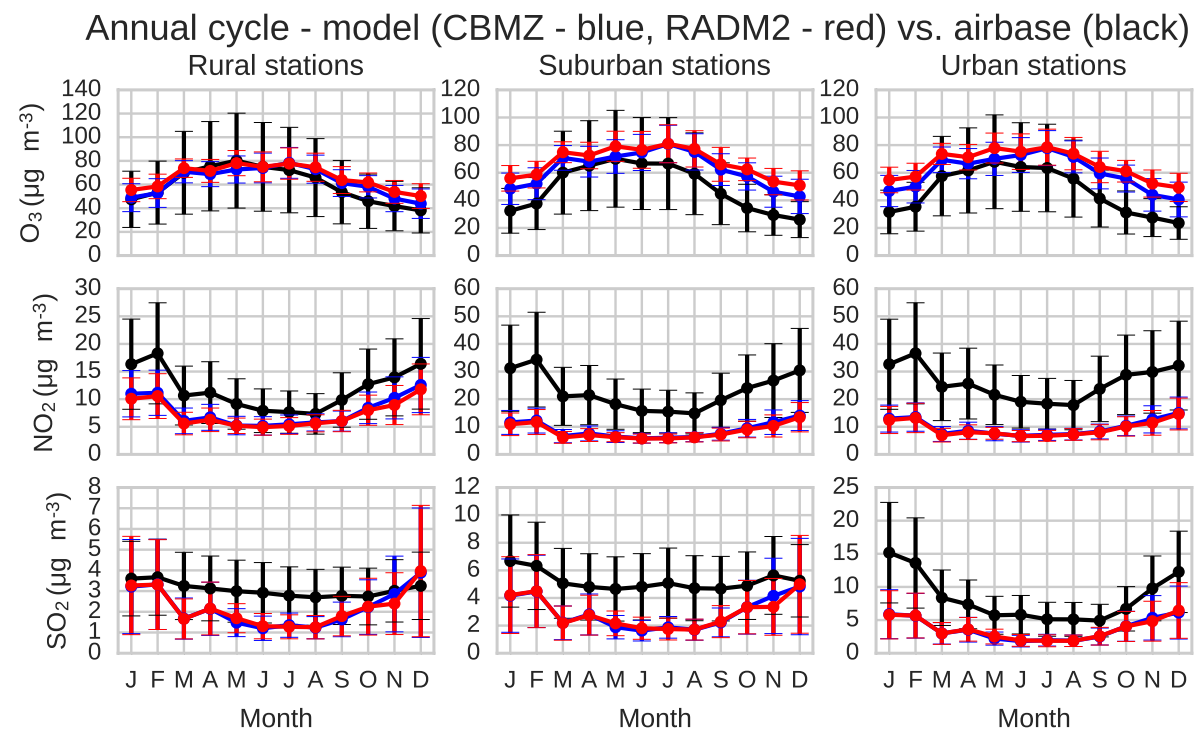

Figure 4. Comparison of monthly gas concentrations between model values (CBMZ - blue, RADM2 - red) and measurements (black). Error bars indicate averaged standard deviation.
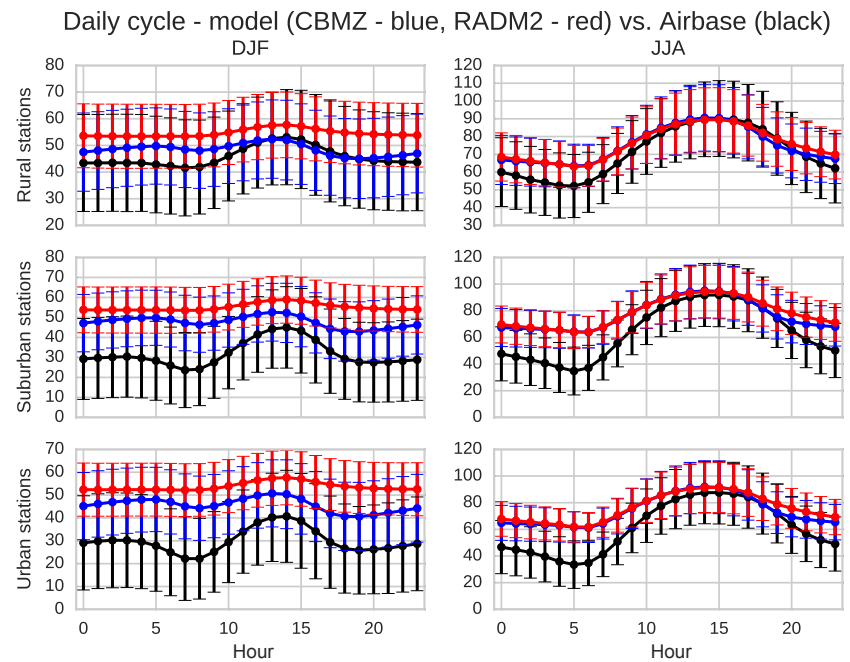

Figure 5. Comparison of ozone averaged daily cycles between model values (CBMZ - blue, RADM2 - red) and measurements (black). Error bars indicate averaged standard deviation over hours.

daily cycle, similarly to Huszar et al. (2012), who invoked the CB-IV chemical mechanism. The simulation with the RADM2 scheme produces only a simple one-mode daily cycle.

The comparison of the two mechanisms further reveals that CBMZ usually provides lower ozone and higher $\mathrm{NO}_{2}$ concentrations than RADM2. This can be connected to more effective NO-titration in CBMZ as identified by Balzarini et al. (2015), who made similar simulations over Europe. Knote et al. (2015) concluded that the uncertainty in predicted $\mathrm{O}_{3}$ in a 3-D model solely due to the choice of gas- phase chemical mechanism should be of the order of $5 \%$, or 4 ppbv. For JJA, our differences lie within this range; however, winter differences are somewhat larger.

\section{Summary and conclusions}

Evaluation of the WRF-Chem model using station data was performed in order to investigate the model's ability to capture surface values of meteorological and gas concentration fields. The amplitude of temperature daily cycle is underestimated by about $1{ }^{\circ} \mathrm{C}$. The total precipitation is overestimated in every season (approximately by $25 \%$ ). Daily and annual cycles of ozone concentration are well captured, while the correlation of daily values with observations is nearly 0.7 . Correlation of $\mathrm{NO}_{2}$ and $\mathrm{SO}_{2}$ daily values is lower, and the overall bias at rural stations reaches almost $-40 \%$ for $\mathrm{NO}_{2}$ and $-30 \%$ for $\mathrm{SO}_{2}$. At suburban and urban stations, the underestimation is much larger.

The differences between CBMZ and RADM2 chemical mechanisms are significant in term of the ozone daily cycle, especially in winter. Here, CBMZ reproduces the daily cycle more accurately. Also in overall statistics (bias, correlation and slope), CBMZ achieves a better match.

This work focused on evaluation of only three gases. For better understanding of the model performance and emission accuracy, model evaluation should be extended to other gases considered by the model for which measurements are available for validation. An even better strategy would be to compare not only surface concentrations, but also to use vertical measurements of the examined gases. As future work, a multi-model and multi-mechanism evaluation including 
satellite column observations is planned in order to achieve as accurate model description of the real state as possible.

Code and data availability. The source code of the WRF-Chem model is publicly available (after registration) on http://www2. mmm.ucar.edu/wrf/users/download/get_source.html. The modeled data used in this study can be provided upon request to the corresponding author.

Competing interests. The authors declare that they have no conflict of interest.

Acknowledgements. This work is supported by the Charles University, projects GA UK No. 115-10/227184 and SVV No. 260327. Authors wish to express their thanks to WRF team community for their development of the model WRF and chemistry modules used in the study. Further, our thanks go to the ECAD team for the E-OBS gridded data and European Environment Agency for AirBase data used for validation and analysis of results. Authors also would like to acknowledge the MACC organization for TNO emission data and the NCAR for MOZART-4/GEOS-5 and Biomass Burning emission data, which are all used in our model simulations.

Edited by: Martin Piringer

Reviewed by: two anonymous referees

\section{References}

Balzarini, A., Pirovano, G., Honzak, L., Žabkar, R., Curci, G., Forkel, R., Hirtl, M., José, R. S., Tuccella, P., and Grell, G.: WRF-Chem model sensitivity to chemical mechanisms choice in reconstructing aerosol optical properties, Atmos. Environ., 115, 604-619, https://doi.org/10.1016/j.atmosenv.2014.12.033, 2015.

Chen, F. and Dudhia, J.: Coupling an Advanced Land SurfaceHydrology Model with the Penn State-NCAR MM5 Modeling System. Part I: Model Implementation and Sensitivity, Mon. Weather Rev., 129, 569-585, 10.1175/15200493(2001)129<0569:CAALSH>2.0.CO;2, 2001.

Chou, M.-D. and Suarez, M. J.: Solar Radiation Parameterization (CLIRAD-SW) for Atmospheric Studies, NASA/TM-1999104606, 15, 1999.

Dee, D. P., Uppala, S. M., Simmons, A. J., Berrisford, P., Poli, P., Kobayashi, S., Andrae, U., Balmaseda, M. A., Balsamo, G., Bauer, P., Bechtold, P., Beljaars, A. C. M., van de Berg, L., Bidlot, J., Bormann, N., Delsol, C., Dragani, R., Fuentes, M., Geer, A. J., Haimberger, L., Healy, S. B., Hersbach, H., Hólm, E. V., Isaksen, L., Kållberg, P., Köhler, M., Matricardi, M., McNally, A. P., Monge-Sanz, B. M., Morcrette, J.-J., Park, B.-K., Peubey, C., de Rosnay, P., Tavolato, C., Thépaut, J.-N., and Vitart, F.: The ERA-Interim reanalysis: configuration and performance of the data assimilation system, Q. J. Roy. Meteorol. Soc., 137, 553597, https://doi.org/10.1002/qj.828, 2011.

Emmons, L. K., Walters, S., Hess, P. G., Lamarque, J.-F., Pfister, G. G., Fillmore, D., Granier, C., Guenther, A., Kinnison, D., Laepple, T., Orlando, J., Tie, X., Tyndall, G., Wiedinmyer, C.,
Baughcum, S. L., and Kloster, S.: Description and evaluation of the Model for Ozone and Related chemical Tracers, version 4 (MOZART-4), Geoscientific Model Development, 3, 43-67, https://doi.org/10.5194/gmd-3-43-2010, 2010.

Grell, G. and Baklanov, A.: Integrated modeling for forecasting weather and air quality: A call for fully coupled approaches, Atmos. Environ., 45, 6845-6851, https://doi.org/10.1016/j.atmosenv.2011.01.017, 2011.

Grell, G. A. and Freitas, S. R.: A scale and aerosol aware stochastic convective parameterization for weather and air quality modeling, Atmos. Chem. Phys., 14, 5233-5250, https://doi.org/10.5194/acp-14-5233-2014, 2014.

Grell, G. A., Peckham, S. E., Schmitz, R., McKeen, S. A., Frost, G., Skamarock, W. C., and Eder, B.: Fully coupled "online" chemistry within the WRF model, Atmospheric Environment, 39, 6957-6975, https://doi.org/10.1016/j.atmosenv.2005.04.027, 2005.

Guenther, A., Karl, T., Harley, P., Wiedinmyer, C., Palmer, P. I., and Geron, C.: Estimates of global terrestrial isoprene emissions using MEGAN (Model of Emissions of Gases and Aerosols from Nature), Atmos. Chem. Phys., 6, 3181-3210, https://doi.org/10.5194/acp-6-3181-2006, 2006.

Haylock, M. R., Hofstra, N., Klein Tank, A. M. G., Klok, E. J., Jones, P. D., and New, M.: A European daily highresolution gridded data set of surface temperature and precipitation for 1950-2006, J. Geophys. Res.-Atmos., 113, d20119, https://doi.org/10.1029/2008JD010201, 2008.

Hong, S.-Y., Noh, Y., and Dudhia, J.: A New Vertical Diffusion Package with an Explicit Treatment of Entrainment Processes, Mon. Weather Rev., 134, 2318-2341, https://doi.org/10.1175/MWR3199.1, 2006.

Huszar, P., Miksovsky, J., Pisoft, P., Belda, M., and Halenka, T.: Interactive coupling of a regional climate model and a chemical transport model: evaluation and preliminary results on ozone and aerosol feedback, Clim. Res., 51, 59-88, 2012.

Huszar, P., Belda, M., and Halenka, T.: On the long-term impact of emissions from central European cities on regional air quality, Atmos. Chem. Phys., 16, 1331-1352, https://doi.org/10.5194/acp-16-1331-2016, 2016.

Im, U., Bianconi, R., Solazzo, E., Kioutsioukis, I., Badia, A., Balzarini, A., Baró, R., Bellasio, R., Brunner, D., Chemel, C., Curci, G., Flemming, J., Forkel, R., Giordano, L., JiménezGuerrero, P., Hirtl, M., Hodzic, A., Honzak, L., Jorba, O., Knote, C., Kuenen, J. J., Makar, P. A., Manders-Groot, A., Neal, L., Pérez, J. L., Pirovano, G., Pouliot, G., Jose, R. S., Savage, N., Schroder, W., Sokhi, R. S., Syrakov, D., Torian, A., Tuccella, P., Werhahn, J., Wolke, R., Yahya, K., Zabkar, R., Zhang, Y., Zhang, J., Hogrefe, C., and Galmarini, S.: Evaluation of operational on-line-coupled regional air quality models over Europe and North America in the context of \{AQMEII \} phase 2. Part I: Ozone, Atmos. Environ., 115, 404420, https://doi.org/10.1016/j.atmosenv.2014.09.042, 2015.

Knote, C., Tuccella, P., Curci, G., Emmons, L., Orlando, J. J., Madronich, S., Baró, R., Jiménez-Guerrero, P., Luecken, D., Hogrefe, C., Forkel, R., Werhahn, J., Hirtl, M., Pérez, J. L., José, R. S., Giordano, L., Brunner, D., Yahya, K., and Zhang, Y.: Influence of the choice of gas-phase mechanism on predictions of key gaseous pollutants during the \{AQMEII 
phase-2 intercomparison, Atmos. Environ., 115, 553-568, https://doi.org/10.1016/j.atmosenv.2014.11.066, 2015.

Kuhn, M., Builtjes, P. J. H., Poppe, D., Simpson, D., Stockwell, W. R., Andersson-Sköld, Y., Baart, A., Das, M., Fiedler, F., Hov, Ø., Kirchner, F., Makar, P. A., Milford, J. B., Roemer, M. G. M., Ruhnke, R., Strand, A., Vogel, B., and Vogel, H.: Intercomparison of the gas-phase chemistry in several chemistry and transport models, Atmos. Environ., 32, 693-709, https://doi.org/10.1016/S1352-2310(97)00329-4, 1998.

Mar, K. A., Ojha, N., Pozzer, A., and Butler, T. M.: Ozone air quality simulations with WRF-Chem (v3.5.1) over Europe: model evaluation and chemical mechanism comparison, Geosci. Model Dev., 9, 3699-3728, https://doi.org/10.5194/gmd-9-3699-2016, 2016.

Misenis, C. and Zhang, Y.: An examination of sensitivity of WRF/Chem predictions to physical parameterizations, horizontal grid spacing, and nesting options, Atmos. Res., 97, 315-334, https://doi.org/10.1016/j.atmosres.2010.04.005, 2010.

Mlawer, E. J., Taubman, S. J., Brown, P. D., Iacono, M. J., and Clough, S. A.: Radiative transfer for inhomogeneous atmospheres: RRTM, a validated correlated-k model for the longwave, J. Geophys. Res.-Atmos., 102, 16663-16682, https://doi.org/10.1029/97JD00237, 1997.

Morrison, H., Thompson, G., and Tatarskii, V.: Impact of Cloud Microphysics on the Development of Trailing Stratiform Precipitation in a Simulated Squall Line: Comparison of One- and Two-Moment Schemes, Mon. Weather Rev., 137, 991-1007, https://doi.org/10.1175/2008MWR2556.1, 2009.
Stockwell, W., Middleton, P., Chang, J., and Tang, X.: The second generation regional acid deposition model chemical mechanism for regional air quality modeling, J. Geophys. Res., 95, 1634316367, https://doi.org/10.1029/JD095iD10p16343, 1990.

Tuccella, P., Curci, G., Visconti, G., Bessagnet, B., Menut, L., and Park, R. J.: Modeling of gas and aerosol with WRF/Chem over Europe: Evaluation and sensitivity study, J. Geophys. Res.Atmos., 117, D03303, https://doi.org/10.1029/2011JD016302, 2012.

Vautard, R., Builtjes, P., Thunis, P., Cuvelier, C., Bedogni, M., Bessagnet, B., Honoré, C., Moussiopoulos, N., Pirovano, G., Schaap, M., Stern, R., Tarrason, L., and Wind, P.: Evaluation and intercomparison of Ozone and $\{$ PM10 $\}$ simulations by several chemistry transport models over four European cities within the CityDelta project, Atmos. Environ., 41, 173-188, https://doi.org/10.1016/j.atmosenv.2006.07.039, 2007.

Wiedinmyer, C., Akagi, S. K., Yokelson, R. J., Emmons, L. K., AlSaadi, J. A., Orlando, J. J., and Soja, A. J.: The Fire INventory from NCAR (FINN): a high resolution global model to estimate the emissions from open burning, Geosci. Model Dev., 4, 625641, https://doi.org/10.5194/gmd-4-625-2011, 2011.

Zaveri, R. A. and Peters, L. K.: A new lumped structure photochemical mechanism for large-scale applications, J. Geophys. Res.-Atmos., 104, 30387-30415, https://doi.org/10.1029/1999JD900876, 1999. 